\title{
A preventive practice and its educational role with an academic community of Dentistry
}

Luiza Foltran de Azevedo Koch*; Paula Porto Spada*; Elvira Katherine Barriga Flores*; Carla Castiglia Gonzaga**; Rafaela Scariot**; Carmen Lucia Mueller Storrer**

* Postgraduate student, School of Health Science, Universidade Positivo, Curitiba

** Professor, School of Health Science, Universidade Positivo, Curitiba

Received February 12, 2019. Approved June 2, 2019.

\begin{abstract}
The study aimed to verify the adherence of undergraduate Dentistry students to the hepatitis B and tetanus vaccination campaign in a private Dental school. The hypothesis tested was that the vaccination campaign would be an effective program in prevention of $\mathrm{HBV}$ and tetanus infection. The vaccination's card copies and the Anti-HBs exam were analyzed as main outcome. Data were submitted to bivariate and multivariate Poisson regression analyses $(\alpha<0.05)$. Age, admission year, studying shift, doses of hepatitis B and tetanus vaccinations were independent variables. Out of the 485 students, 318 delivered the vaccination's card, and 295 presented the Anti-HBs exam. The median age of the students was 21 years $(76.1 \%$ female and $23.9 \%$ male $)$. In the univariate and multivariate Poisson regression model, failure to receive the tetanus vaccination was considered as a risk factor. Undergraduate students enrolled in the initial years were more likely to have not received the vaccination than the senior years $(\mathrm{p} \leq 0.001)$. Out of the total number of students (318) who submitted the documentation for hepatitis B, 86.1\% completed the vaccination protocol (3 doses), while $13.9 \%$ the incomplete protocol ( 1 or 2 doses). Older students were more likely to have refrained from taking the vaccinations compared to younger $(\mathrm{p} \leq 0.001)$. In relation to the Anti-HBs, $73.9 \%$ had positive protective titer. Vaccination campaigns for undergraduate students may be effective if adherence of the individuals to the schedule can be ensured. Strategies for greater adherence of students, should be thought and planned by Dental Schools.
\end{abstract}

Descriptors: Students. Immunization. Hepatitis B. Tetanus. 


\section{INTRODUCTION}

Dentists may be at a higher risk of certain infections due to frequent exposure to blood and body fluids. This risk is higher during the period of professional training ${ }^{1}$; therefore, dental schools should conduct awareness programs to educate students about hepatitis B and tetanus infections $^{1,2}$. In Brazil, according to the Brazilian National Curriculum Guidelines (DCN), the dentists' training aim to give the students the knowledge required for the practice of the profession. Among these requirements it is necessary for the futures professionals to be aware of the rules of workers in the oral health area in society and to have personal responsibility ${ }^{3}$.

Hepatitis B virus (HBV) infection is an inflammatory disease of the liver and is the most common viral infection ${ }^{4}$. The routes of transmission of HBV include unprotected sexual contact, blood transfusion, reuse of contaminated needles, and vertical transmission from mother to child during pregnancy ${ }^{5}$. In dental practice, the most common mode of transmission of the infection is through percutaneous exposure (needle stick injuries) and also by contact with blood or saliva of the infected individual. Studies have confirmed the possibility of transmission of HBV by exposure to saliva and gingival crevicular fluid, which increases the vulnerability of oral health professionals to hepatitis infection ${ }^{4,6}$.

Tetanus is a non-contagious, infectious disease caused by the action of exotoxins produced by Clostridium tetani. The bacteria exist in the form of spores, and can be identified on animals' skin, on the ground, branches of trees, shrubs, rotting water, street dust, animals' intestinal tract, and feces. The infection occurs by the introduction of spores in solution of continuity of the skin and the mucosa. Tetanus can be prevented by immunization, and healthcare professionals are recommended to be vaccinated against the infection ${ }^{7}$.

Immunization of healthcare professionals and students is an effective method to control the occupational risk in the personnel as well as the risk of infection in patients. Immunity against $\mathrm{HBV}$ is demonstrated by the concentration of Anti-HBs antibodies in the blood, and a value of $\geq 10 \mathrm{mIU} / \mathrm{mL}$ is considered seroprotective. In contrast, no test is required to confirm immunity against tetanus; however, a booster vaccination dose is indicated at intervals of every 10 years ${ }^{8}$.

Thus, the objective of the present study was to verify the adherence of undergraduate students to the hepatitis $\mathrm{B}$ and tetanus vaccination campaign at a private Dental school. The hypothesis tested was that the vaccination campaign would be an effective program in prevention of HBV and tetanus infection among undergraduate Dental students.

\section{MATERIALS AND METHODS}

The present study was approved by the Ethics Committee of number 062975/2017. The sample comprised students enrolled in a private Dental school in the year 2017. The participation of the students was voluntary and a total of 318 participants enrolled in the vaccination campaign.

The data were collected from the physical archives that stored the documents provided by the undergraduate students for the program "Vaccination Campaign". The data were cataloged by class, based on the list of students enrolled in the year 2017. The copy of the vaccination card and the results of the Anti-HBs examination were analyzed from the students who submitted the documents.

Information such as age, admission year, studying shift, doses of hepatitis B and tetanus vaccinations was verified. Anti-HBs test (reference value $\geq 10 \mathrm{IU}$ ) was also performed to 
confirm the status of immunization.

The data were submitted to bivariate and multivariate Poisson regression analyses, with a confidence level of 0.05 using IBM SPSS 21 statistics software.

\section{RESULTS}

All the students enrolled in the Dental school $(n=485)$ between years 2014-2017 were invited to participate in the vaccination campaign. From the total number of students, only those who submitted the vaccination-related documentation (hepatitis B and tetanus) $(n=318)$ were included in the sample. The median age of the students was 21 years, ranging from 16 to 44 years of age. There were $217(68.2 \%)$ female (68.2\%) and 101 (31.8\%) male students. Most of the students $(64 \%)$ attended school during the day, while $39 \%$ attended in the night.

For data analysis, the age of the included students was dichotomized $(\leq 20$ years old and $>$
20 years old), from the median (21 years old). The period of attendance was also dichotomized based on the initial (1st and 2nd) and senior (3rd and 4th) years.

In the univariate Poisson regression model, failure to receive the tetanus vaccination was considered as a risk factor. The results demonstrated that older students were more likely to have refrained from taking the vaccination compared to younger students [p =0.048 / RP: 2.70 (1.00 - 7.25)].

No association was observed with gender of the included students $(\mathrm{p}=0.532)$. Undergraduate students enrolled in the initial years of the course were more likely to have not received the vaccination than students in the senior years [p S0.001 / RP: 8.02 (2.39-26.84)]. The students who attended the school during the night were more likely to have not received the tetanus vaccine compared to those who attended during the day [p = 0.002 / RP: $4.75(1.77-12.77)]$ (table 1).

Table 1. Distribution of tetanus variable through univariate and multivariate analyses

\begin{tabular}{|c|c|c|c|c|c|c|}
\hline \multirow[b]{2}{*}{ Variables } & \multicolumn{2}{|c|}{ Tetanus } & \multicolumn{2}{|c|}{ Bivariate } & \multicolumn{2}{|c|}{ Multivariate } \\
\hline & $\mathbf{N}$ & $(\%)$ & p value & RP brut & p value & RP adjusted \\
\hline \multicolumn{7}{|l|}{ Age (Years) } \\
\hline$\leq 20$ & 209 & 43.1 & reference & - & reference & - \\
\hline$>20$ & 276 & 56.9 & 0.048 & $2.70(1.00-7.25)$ & 0.006 & $3.60(1.44-8.97)$ \\
\hline \multicolumn{7}{|l|}{ Gender } \\
\hline Male & 116 & 23.9 & reference & - & - & - \\
\hline Female & 369 & 76.1 & 0.532 & $0.68(0.20-2.26)$ & - & - \\
\hline \multicolumn{7}{|l|}{ Series } \\
\hline Initial & 220 & 45.4 & $\leq 0.001$ & $8.02(2.39-26.84)$ & $\leq \mathbf{0 . 0 0 1}$ & $9.76(3.18-29.97)$ \\
\hline Final & 265 & 54.6 & reference & - & reference & - \\
\hline \multicolumn{7}{|l|}{ Shift } \\
\hline Daytime & 307 & 63.3 & 0.002 & $4.75(1.77-12.77)$ & 0.034 & $2.73(1.08-6.93)$ \\
\hline Night & 178 & 36.7 & reference & - & reference & - \\
\hline
\end{tabular}

Bold values indicate a statistically significant difference $(\mathrm{p}<0.05)$, univariate and multivariate Poisson regression.

In the multivariate and univariate Poisson regression model, association was observed between all variables.
Out of the total number of students (318) who submitted the documentation for hepatitis B, $274(86.1 \%)$ completed the vaccination protocol 
(3 doses), while 44 (13.9\%) underwent the incomplete protocol ( 1 or 2 doses). The data used for statistical analyses belonged to the 295 students who presented the reports of the AntiHBs investigation. Among these, 218 (73.9\%) students had values above $10 \mathrm{IU}$, and were immune to hepatitis B, while 77 (26.1\%) presented results lower than $10 \mathrm{IU}$.

In the univariate Poisson regression model, the same risk factors as those considered for tetanus were used. The results demonstrated that older students were more likely to have refrained from taking the vaccinations compared to younger students [ $\mathrm{p} \leq 0.001 / \mathrm{RP}: 2.05(1.36$ 3.08)]. Undergraduate students enrolled in the initial years of the course were more likely to have not received the vaccine than students in the senior years $[\mathrm{p} \leq 0.001 / \mathrm{RP}: 2.47$ (1.70-3.59)]. Students who attended school in the night were more likely to have not received the vaccination compared to those who attended during the day [p = 0.03/RP: 1.52 (1.04-2.22)].

The analysis included students who underwent the complete and incomplete protocols for hepatitis B vaccination. Students who received all the three doses of hepatitis vaccination were more likely to be immunized against the disease [( $\mathrm{p}=0.04 / \mathrm{RP}: 1.86$ (1.222.83)]. The results have been depicted in table 2 . In the multivariate Poisson regression model, no correlation was observed between the univariate and multivariate variables $(\mathrm{p}<0.05)$.

Table 2. Univariate and multivariate regression analyses for hepatitis B

\begin{tabular}{|c|c|c|c|c|c|c|}
\hline \multirow[b]{2}{*}{ Variables } & \multicolumn{2}{|c|}{ Hepatitis } & \multicolumn{2}{|c|}{ Bivariate } & \multicolumn{2}{|c|}{ Multivariate } \\
\hline & $\mathbf{N}$ & $(\%)$ & $\begin{array}{c}p \text { value } \\
\text { not adjusted }\end{array}$ & RP $($ IC) & $\begin{array}{c}p \text { value } \\
\text { adjusted }\end{array}$ & RP (IC) \\
\hline \multicolumn{7}{|l|}{ Age (Years) } \\
\hline$\leq 20$ & 140 & 47.5 & reference & & reference & - \\
\hline$>20$ & 155 & 52.5 & $\leq 0.001$ & $2.05(1.36-3.08)$ & $\leq 0.001$ & $2.32(1.52-3.53)$ \\
\hline \multicolumn{7}{|l|}{ Gender } \\
\hline Male & 60 & 22.3 & 0.65 & $1.10(0.72-1.75)$ & - & - \\
\hline Female & 235 & 79.7 & reference & - & reference & - \\
\hline \multicolumn{7}{|l|}{ Series } \\
\hline Initial & 93 & 31.5 & reference & - & reference & - \\
\hline Final & 202 & 68.5 & $\leq 0.001$ & $2.47(1.70-3.59)$ & $\leq \mathbf{0 . 0 0 1}$ & $2.02(1.40-2.91)$ \\
\hline \multicolumn{7}{|l|}{ Shift } \\
\hline Daytime & 187 & 63.4 & 0.03 & $1.52(1.04-2.22)$ & 0.02 & $1.54(1.07-2.23)$ \\
\hline Night & 108 & 36.6 & reference & - & reference & - \\
\hline \multicolumn{7}{|l|}{ Dose } \\
\hline Incomplete & 256 & 86.8 & $\leq 0.001$ & $1.86(1.22-2.83)$ & $\leq 0.001$ & $2.18(1.45-3.27)$ \\
\hline Complete & 39 & 13.2 & reference & & reference & \\
\hline
\end{tabular}

Bold values indicate a statistically significant difference $(\mathrm{p}<0.05)$, Poisson regression.

The median value presented on the AntiHBs investigation for the whole sample was 67.7 IU (0-1638). The Mann-Whitney test was used to verify the association between the Anti-HBs values and the risk factors and was considered statistically significant at $\mathrm{p}<0.05$ (table 3). Regarding the age of the participants, older students presented an Anti-HBs median value of 146.6 (0-1638), while younger students presented with $36.8(0-1000)$, p value $=0.001$. The median value of the senior students who attended in the last year was $114.4(0-1638)$ and of those in the initial years was 16.2 (0-1000), $p$ value $\leq 0.001$. 
Table 3. Results of the Anti-Hbs examination in relation to the variables age, gender, series, and studying shift

\begin{tabular}{|c|c|c|c|c|}
\hline \multirow[b]{2}{*}{ Variables } & \multirow[b]{2}{*}{ Median } & \multicolumn{2}{|c|}{ Anti Hbs } & \multirow[t]{2}{*}{ p values } \\
\hline & & Minimum & Maximum & \\
\hline \multicolumn{5}{|l|}{ Age(Years) } \\
\hline$\leq 20$ & 36.8 & 0 & 1000 & \\
\hline$>20$ & 146.6 & 0 & 1638 & $\leq \mathbf{0 . 0 0 1}$ \\
\hline \multicolumn{5}{|l|}{ Gender } \\
\hline Male & 44.7 & 0 & 1000 & \\
\hline Female & 73.3 & 0 & 1638 & 0.25 \\
\hline \multicolumn{5}{|l|}{ Series } \\
\hline Initial & 16.2 & 0 & 1000 & \\
\hline Final & 114.4 & 0 & 1638 & $\leq \mathbf{0 . 0 0 1}$ \\
\hline \multicolumn{5}{|l|}{ Shift } \\
\hline Daytime & 72.5 & 0 & 1000 & \\
\hline Night & 53.6 & 0 & 1638 & 0.30 \\
\hline
\end{tabular}

\section{DISCUSSION}

The hypothesis tested in the present study regarding effectiveness of the vaccination campaign in preventing $\mathrm{HBV}$ and tetanus infection in undergraduate Dental students has been proven. Out of the total number of students enrolled in the year 2017 ( $\mathrm{n}=485), 318$ submitted the details of the vaccination, and 295 presented the reports of the Anti-HBs investigation. Two hundred and eighteen students (73.9\%) demonstrated protective Anti-HBs titers $(>10$ UI), which did not corroborate with the results reported in the studies by Lasemi et al. $(2011)^{9}$, Sacchetto et al. (2013) $)^{10}$ and Al-Maweri et al. $(2015)^{11}$.

The present retrospective study proposes that schools of dentistry should conduct awareness programs to educate students regarding the importance of vaccination against hepatitis B and tetanus, similar to that suggested by Mahesh et al. (2014) $)^{2}$. Among health professionals, dentists belong to the high-risk group in acquiring such infections, especially during clinical training period due to increased contact with the patient ${ }^{13}$. It is known that the immunization of healthcare professionals and students is an effective method to control the occupational risk, which is higher during the period of professional training ${ }^{1}$. Therefore, vaccination campaigns during the initial years of enrolment to Dental schools are critical. The results of tetanus vaccination in the present study demonstrated that in the initial years, students were more likely to have not received the vaccination than those in the final years. However, older students were more likely to not have received the vaccination compared to younger students. These data demonstrate that campaigns must be conducted and maintained in Dental schools to encourage students to take the vaccinations as per protocol. In our survey, data of 485 students were collected of these only 229 were analyzed. We were able to verify that there was no total adherence to the graded, corroborating with the studies of Sachetto et al. $(2013)^{10}$, Al-Maweri et al. $(2015)^{11}$ and Lasemi et al. $(2011)^{9}$. Possible strategies could be addressed for this problem to be remedied. Performing, at the time of enrollment in the course, the presentation of the vaccination portfolio. The loss of the vaccine document may also be detected as a problem to prove the 
necessary vaccine protocol.

The HBV vaccine is composed of a recombinant $\mathrm{HBV}$ surface antigen ( $\mathrm{HBsAg}$ ), which induces specific antibodies (anti-HBs) and confers $95 \%$ immunity ${ }^{12}$. The immunity acquired through vaccination and natural immunity provide lifelong protection against the infection. Immunity against HBV is demonstrated by the concentration of Anti-HBs antibodies in the blood, with a value of $\geq 10 \mathrm{mIU} / \mathrm{mL}$ being considered seroprotective ${ }^{8}$. However, Anti-HBs levels may decline over time, and many previously vaccinated individuals may exhibit Anti-HBs values below the protective threshold when tested 10-15 years after vaccination ${ }^{14,15}$. These data reiterate the importance of continuation of vaccination campaigns and periodic repetition of Anti-HBs investigations. The results of the present study showed that older students were more likely to not have received the vaccine compared to younger students.

Out of the total number of students (318) who submitted the documentation for hepatitis B, $274(86.1 \%)$ completed the vaccination protocol (3 doses) while 44 (13.9\%) underwent the incomplete protocol (1 or 2 doses). The percentage of students with Anti-HBs values above 10 IU (immune to hepatitis B) was $73.9 \%$, while $26.1 \%$ students presented results lower than 10 IU. Similar results were reported in a study by Lasemi et al. $(2011)^{9}$, wherein $75.8 \%$ of the students demonstrated immune response. In a study by Sacchetto et al. $(2013)^{10}, 126$ out of 159 students $(79.2 \%)$ were immune to hepatitis B. Determination of the appropriate dose of the Anti-HBs vaccination is crucial to achieve adequate response, as failure to achieve protective antibody levels may indicate the need for subsequent booster doses ${ }^{15}$.

The present study included the data of students who underwent the complete and incomplete protocols of hepatitis B vaccination.
As expected, students who received three doses of the vaccination were more likely to be immunized against the disease. Occasionally, low or lack of response after the recommended doses of vaccines may be reported in elderly individuals with immunodeficiency, chronic diseases, or cancer. In such cases, an additional dose of the vaccine, known as booster dose, may be recommended. Double-dose re-vaccination may be recommended in cases of non-response to the booster dose. Non-response to the doubledose should be considered as a non-sustained response to vaccination; therefore, should not be repeated $^{16}$. In the present study, the booster dose was not evaluated, but future studies should analyze its effectiveness.

In the present study, information about the vaccination status of each student was obtained from the physical records provided by each student. This manner of acquisition of information was different from other studies, wherein self-administered questionnaires were used $^{2,10,11,16}$. The studies also obtained information of the Anti-HBs investigation ${ }^{10}$.

The evidence of effectiveness of vaccinations in the control of infectious diseases with high risk of transmission in dental health care settings is necessarily indirect, as field or clinical trials are not available. Such evidence could be used as a basis to design an immunization program specifically directed towards dental health care personnel ${ }^{17}$.

In Brazil, since the beginning of the nineteenth century, vaccines are used as a measure of disease control, but only in 1973 the National Immunization Program (PNI) was formulated. Anti-hepatitis B (HB) vaccine was included into the basic vaccination schedule in Brazil in 1998, with the first dose being given at birth. In the public health network, this vaccine is also freely offered, and health care worker are included groups for immunization ${ }^{17}$ 
According to the Immunization Action Coalition, supported by the Centers for Disease Control and Prevention (CDC), the Tetanus, Diphtheria, Pertussis (Tdap) vaccine has been recommended. Health education programs are essential to create awareness about tetanus, reiterating that vaccination is the best form of prevention, as the results of the present study demonstrated. It is essential to establish a vaccination campaign in Dental Schools to prevent occurrence of infectious diseases in undergraduate healthcare students.

\section{CONCLUSION}

Vaccination campaigns for undergraduate students may be effective, if adherence of the individuals to the schedule can be ensured. Strategies for greater adherence of students, like this campaign, should be thought and planned by Dental Schools for safety in caring for patients regarding the transmission of diseases such as hepatitis B and tetanus.

\section{RESUMO \\ Prática preventiva e seu papel educacional junto a uma comunidade acadêmica de Odontologia}

O estudo objetivou verificar a adesão dos estudantes de graduação em Odontologia à campanha de vacinação contra hepatite $\mathrm{B}$ e tétano em uma escola particular de Odontologia. A hipótese testada foi que a campanha de vacinação seria um programa efetivo na prevenção da infecção pelo $\mathrm{HBV}$ e tétano. $\mathrm{O}$ cartão de vacinação e o exame anti-HBs foram analisados como desfecho principal. Os dados foram submetidos à regressão de Poisson bivariada e multivariada $(\alpha<0,5)$. Idade, ano de admissão, turno de estudos, número de doses de vacinas para hepatite $B$ e vacinação para tétano foram variáveis independentes. Dos 485 estudantes, 318 entregaram a cópia do cartão de vacinação e 295 apresentaram o exame anti-HBs. A mediana de idade dos estudantes foi de 21 anos $(76,1 \%$ do sexo feminino, $23,9 \%$ do sexo masculino). Nos modelos de regressão de Poisson univariada e multivariada, a não vacinação contra o tétano foi considerada fator de risco. Os alunos de graduação matriculados nos anos iniciais foram mais propensos a não receberem a vacinação do que aqueles dos anos finais $(p \leq 0,001)$. Do total de alunos (318) que entregaram a documentação para hepatite B, $86,1 \%$ completaram o protocolo de vacinação (3 doses), enquanto $13,9 \%$ o protocolo incompleto (1 ou 2 doses). Os estudantes mais velhos foram mais propensos a não terem tomado as vacinas em comparação com mais jovens $(p \leq 0,001)$. Em relação ao anti-HBs, 73,9\% apresentaram título de proteção positivo. As campanhas de vacinação para estudantes de graduação podem ser efetivas se a adesão dos indivíduos ao calendário vacinal puder ser assegurada. Estratégias para maior adesão dos estudantes, como essa campanha, devem ser pensadas e planejadas pelos cursos de Odontologia.

Descritores: Estudantes. Imunização. Hepatite B. Tétano.

\section{REFERENCES}

1. Weber DJ, Rutala WA, Schaffner W. Lessons learned: protection of healthcare workers from infectious disease risks. Crit Care Med. 2010; 38 (8 Suppl):S306-14.

2. Mahesh R, Arthi C, Victor S, Ashokkumar S. Hepatitis B infection awareness among Dental graduate students: A cross sectional study. Int Sch Res Notices. 2014; 29: 389274.

3. Brasil, Ministério da Educação Conselho Nacional de Educação. Diretrizes Curriculares Nacionais dos Cursos de Graduação em Odontologia. [Cited Feb. 20, 2019]. Available at: http://portal.mec.gov. br/cne/arquivos/pdf/CES032002.pdf.

4. Liang TJ. Hepatitis B: the virus and disease. Hepatology. 2009;49:S13-S21.

5. Kolawole OM, Wahab AA, Adekanle DA, Sibanda T, Okoh AI. Seroprevalence of hepatitis B surface antigenemia and its 
effects on hematological parameters in pregnant women in Osogbo, Nigeria. Virol J. 2012;9:317.

6. Lamster IB, Ahlo JK. Analysis of gingival crevicular fluid as applied to the diagnosis of oral and systemic diseases. Ann N Y Acad Sci. 2007 1098:216-29.

7. Maynard JE, Kane MA, Hadler SC. The global control of hepatitis B through vaccination. The role of hepatitis $B$ vaccine in the Expanded Programme on Immunization (EPI); 1986. 19 p.

8. Chaves SS, Fischer G, Groeger J, Patel PR, Thompson ND, Teshale EH, et al. Persistence of long-term immunity to hepatitis B among adolescents immunized at birth. Vaccine. 2012; 30:1644-9.

9. Lasemi E, Haddadpour N, Navi F, Rakhshan A, Rakhshan V. Rate of acquired immunity in Dental students after Hepatitis B vaccination. Dent Res J (Isfahan). 2011;8(3):12831.

10. Sacchetto MS, Barros SS, Araripe TA, Silva AM, Faustino SK, da Silva JM. Hepatitis B: knowledge, vaccine situation and seroconversion of Dentistry students of a public university. Hepat Mon. 2013 Oct 5;13(10) :e13670.

11. Al-Maweri SA, Tarakji B, Shugaa-Addi B, Al-Shamiri HM, Alaizari NA, Masri OA. Infection control: knowledge and compliance among Saudi undergraduate dental students. GMS Hyg Infect Control 2015; $1: 10$

12. Sernia S, Ortis M, Antoniozzi T, Maffongelli E, La Torre G. Levels of Anti-HBs antibody in HBV-vaccinated students enrolled in the Faculty of Medicine, Dentistry and Health Professions of a large Italian University. Biomed Res Int. 2015; 2015:712020.
13. Bagheri-Jamebozorgi JM, Keshavarz J, Nemati M, Mohammadi HS, Rezayati MT, Nejad M, et al. The persistence of anti-HBs antibody and anamnestic response 20 years after primary vaccination with recombinant hepatitis B vaccine at infancy. Hum Vaccin Immunother. 2014; 10:3731-36.

14. Honorati MC, Palareti A, Dolzani P, Busachi CA Rizzoli R, Facchini A. A mathematical model predicting anti-hepatitis $\mathrm{B}$ virus surface antigen (HBs) decay after vaccination against hepatitis B. Clin Exp Immunol. 1999 Apr;116(1):121-6.

15. Leuridan E. Van Damme P. Hepatitis B and the need for a booster dose. Clin Infect Dis. 2011 Jul 1;53(1):68-75.

16. Singh A, Purohit BM, Bhambal A, Saxena S, Gupta A. Knowledge, attitudes, and practice regarding infection control measures among dental students in Central India. J Dent Educ. 2011 Mar;75(3):421-7.

17. Petti S, Messano GA, Polimeni A. Dentist's awarenss toward vaccine preventable diseases. Vaccine. 2011 Oct 19;29(45):810812.

18. Brasil. Ministério da Saúde. Secretaria de Vigilância em Saúde. Departamento de Vigilância das Doenças Transmissíveis. Manual de Normas e Procedimentos para Vacinação / Ministério da Saúde, Secretaria de Vigilância em Saúde, Departamento de Vigilância das Doenças Transmissíveis. Brasília : Ministério da Saúde, 2014. 176 p. : il.

\section{Correspondence to:}

Carmen Lúcia Mueller Storrer

e-mail: carmen.storrer@up.edu.br

Rua Prof. Pedro Viriato Parigot de Souza, 5300

Cidade Industrial

81.280-330 Curitiba/PR Brazil 